\title{
Index of Authors
}

Adelekan, D. A. \& Thurnham, D. 1. Glutathione peroxidase (EC 1.11.1.9) and superoxide dismutase (EC 1.15.1.1) activities in riboflavin-deficient rats infected with Plasmodium berghei malaria 305.

Adlercreutz, H. see Mazur, W. M. 37.

Ahluwalia, N. S. see Wells, Anita S. 23.

Aitken, Raymond P. see Palmer, Robert M. 351.

Alméras, Natalie see Tremblay, Angelo 413.

Amarri, S., Coward, W. A., Harding, M. \& Weaver, L. T. Importance of measuring $\mathrm{CO}_{2}$-production rate when using ${ }_{13} \mathrm{C}$-breath tests to measure fat digestion (Technical note) 541. Anderson, D. H. see Kyriazakis, I. 55.

Anderton, Kay L. see Salter, Andrew M. 195.

Andrés, Pedro see Ortega, Rosa M. 431.

Andrés, Pedro see Ortega, Rosa M. 501.

Atkinson, C. see Bingham, S. A. 393.

Avella, Michael A. see Lambert, Marc S. 203.

Balcells, J. see Pérez, J. F. 237.

Balcells, J., Ganuza, J. M., Pérez, J. F., Martín-Orúe, S. M. \& González Ronquillo, M. Urinary excretion of purine derivatives as an index of microbial-nitrogen intake in growing rabbits 373.

Bardocz, S. see Pusztai, A. 213.

Barker, Margo E. Good Nutrition? fact \& fashion in dietary advice (Book review) 311.

Barrell, Graham K. see Dynes, Robyn A. 47.

Bates, C. J, see Tsuchiya, H. 313.

Bäurle, Wolfgang, Brösicke, Herbert, Matthews, Dwight E., Pogan, Karin \& Fürst, Peter Metabolism of parenterally administered fat emulsions in the rat: studies of fatty acid oxidation with $1{ }^{13} \mathrm{C}$ - and $8{ }^{13} \mathrm{C}$-labelled triolein 381.

Beever, D. E. see Hanigan, M. D. 63.

Benito, Paloma, House, William \& Miller, Dennis Comparison of oral and intraperitoneal iron supplementation in anaemic rats: a re-evaluation of the mucosal block theory of iron absorption 533.

Bennett, Andrew J. see Salter, Andrew M. 195.

Benzie, I. F. F. Antioxidants in Science, Technology, Medicine and Nutrition (Book review) 473.

Bernard, Christine see Zabielski, Romuald 287.

Bernier, J. F. see van Milgen, J. 509.

Billett, Michael A. see Salter, Andrew M. 195.

Bingham, Sheila A. see Loktionov, Alexandre 133.

Bingham, S. A., Atkinson, C., Liggins, J., Bluck, L. \& Coward, A. Phyto-oestrogens: where are we now? (Review article) 393.

Bluck, L. see Bingham, S. A. 393.

Boer, Huug see Groot, Jeroen C. J. 519.

Botham, Kathleen M. see Lambert, Marc S. 203.

Botting, H. G. see Sarwar, G. 129.

Bouchard, Claude see Tremblay, Angelo 413.

Boucher, B. J. Inadequate vitamin $D$ status: does it contribute to the disorders comprising syndrome ' $X$ '? (Review article) 315.

Broadhurst, C. Leigh, Cunnane, Stephen C. \& Crawford, Michael A. Rift Valley lake fish and shellfish provided brain-specific nutrition for early Homo (Review article) 3.

Broadhurst, C. Leigh, Cunnane, Stephen C. \& Crawford, Michael A. Dietary lipids and evolution of the human brain (Reply) (Nutrition Discussion Forum) 390.

Brösicke, Herbert see Bäurle, Wolfgang 381.
Brouns, Fred \& van der Vusse, Ger J. Utilization of lipids during exercise in human subjects: metabolic and dietary constraints (Review article) 117.

Brouwer, D. A. Janneke, van Beek, Jackelien, Ferwerda, Harri, Brugman, Astrid M., van der Klis, Fiona R. M., van der Heiden, H. Jacoline \& Muskiet, Frits A. J. Rat adipose tissue rapidly accumulates and slowly releases an orally-administered high vitamin $D$ dose 527.

Bruce, Jennifer S. see Salter, Andrew M. 195.

Brugman, Astrid M. see Brouwer, D. A. Janneke 527.

Buchan, W. C. see Pusztai, A. 213.

Buttery, Peter J. see Dawson, Janet M. 275.

Buttriss, Judy see Margetts, Barrie 225.

Capitan, Pierre see Savary, Isabelle 297.

Carter, Sophie see Mathers, J. C. 223.

Cashman, Kevin D. see Ginty, Fiona 343.

Castleden, Mark see Gariballa, Salah E. 481.

Chayvialle, Jean Alain see Zabielski, Romuald 287.

Cebrián, J. A. see Pérez, J. F. 237.

Clarke, Lynne, Heasman, Lindsay, Juniper, Darren T. \& Symonds, Michael E. Maternal nutrition in early-mid gestation and placental size in sheep 359.

Cook, James D. see Hurrell, Richard F. 31.

Coward, A. see Bingham, S. A. 393.

Coward, W. A. see Amarri, S. 541.

Cox, Vanessa see Robinson, Siân 249.

Craigon, Jim see Dawson, Janet M. 275.

Crawford, Michael A. see Broadhurst, C. Leigh 3.

Crawford, Michael A. see Broadhurst, C. Leigh 390.

Cruz, Martha L. see Evans, Kevin 425.

Cullinan, Timothy R. see Huddle, Janet-Marie 257.

Cummings, John H. see Loktionov, Alexandre 133.

Cunnane, Stephen C. see Broadhurst, C. Leigh 3.

Cunnane, Stephen C. see Broadhurst, C. Leigh 390.

Dardevet, Dominique see Savary, Isabelle 297.

Dardillat, Claude see Zabielski, Romuald 287.

Darling, P. see Sarwar, G. 129.

Davidsson, Lena see Hurrell, Richard F. 31.

Davis, T. A. see Sarwar, G. 129.

Dawson, Janet M., Greathead, Henry M. R., Craigon, Jim, Hachey, David L., Reeds, Peter J., Pell, Jennifer M. \& Buttery, Peter J. The interaction between nutritional status and growth hormone in young cattle: differential responsiveness of fat and protein metabolism 275.

De Boever P. see de Smet, I. 185.

Debras, Elisabeth see Savary, Isabelle 297

de Carvalho, A. F. F. U. see Pusztai, A. 213.

Denne, Jonathan see Robinson, Siân 249.

De Smet, I., De Boever, P. \& Verstraete, W. Cholesterol lowering in pigs through enhanced bacterial bile salt hydrolase activity 185.

Després, Jean-Pierre see Tremblay, Angelo 413.

De Wet, T. see Harris, H. E. 489.

Dhamoa, M. S. see France, J. 314.

Dijkstra, J. see France, J. 314.

Dincer, Zuhal see Haywood, Susan 329.

Doucet, Eric see Tremblay, Angelo 413.

Drapeau, Vicky see Tremblay, Angelo 413.

Dubois, S. see van Milgen, J. 509. 
Dulloo, A. G. Partitioning between protein and fat during starvation and refeeding: is the assumption of intra-individual constancy of P-ratio valid? (Nutrition Discussion Forum) 107.

Duncan, A. J. see Kyriazakis, I. 55.

Dynes, Robyn A., Poppi, Dennis P., Barrell, Graham K. \& Sykes, Andrew R. Elevation of feed intake in parasite-infected lambs by central administration of a cholecystokinin receptor antagonist 47 .

Elia, M. see James, L. A. 365.

Ellison, G. T. H. see Harris, H. E. 489.

Erbersdobler, Helmut F. see Trautwein, Elke A. 463.

Evans, Kevin, Kuusela, Pertti J., Cruz, Martha L., Wilhelmova, Ingrid, Fielding, Barbara A. \& Frayn, Keith N. Rapid chylomicron appearance following sequential meals: effects of second meal composition 425.

Ewen, S. W. B. see Pusztai, A. 213.

Ferwerda, Harri see Brouwer, D. A. Janneke 527.

Fielding, Barbara A. see Summers, Lucinda K. M. 141.

Fielding, Barbara A. see Evans, Kevin 425.

Flynn, Albert see Ginty, Fiona 343.

France, J. see Hanigan, M. D. 63.

France, J., Lopez, S., Dijkstra, J. \& Dhamoa, M. S. Particulate matter loss and the nylon-bag method (Reply) (Corrigenda) 314.

Frayn, Keith N. 'Judge not according to the appearance' (Editorial) 1.

Frayn, Keith N. see Summers, Lucinda K. M. 141.

Frayn, Keith see Margetts, Barrie 225.

Frayn, Keith N. see Evans, Kevin 425.

Fürst, Peter see Bäurle, Wolfgang 381.

Ganuza, J. M. see Balcells, J. 373.

Gariballa, Salah E., Parker, Stuart G., Taub, Nick \& Castleden, Mark. Nutritional status of hospitalized acute stroke patients 481.

Ghusain-Choueiri, A. see Henry, C. J. K. 109.

Gibney, Michael J. see Roche, Helen M. 419.

Gibson, Rosalind S. see Huddle, Janet-Marie 257.

Ginty, Fiona, Flynn, Albert and Cashman, Kevin D. The effect of dietary sodium intake on biochemical markers of bone metabolism in young women 343.

Godfrey, Keith see Robinson, Siân 249.

González Ronquillo, M. see Balcells, J. 373.

Grant, G. see Pusztai, A. 213.

Greathead, Henry M. R. see Dawson, Janet M. 275.

Grizard, Jean see Savary, Isabelle 297.

Groot, Jeroen C. J., Williams, Barbara A., Oostdam, Arno J., Boer, Huug \& Tamminga, Seerp. The use of cumulative gas and volatile fatty acid production to predict in vitro fermentation kinetics of Italian ryegrass leaf cell walls and contents at various time intervals 518.

Guilloteau, Paul see Zabielski, Romuald 287.

Gurr, M. I. Dietary lipids and evolution of the human brain (Nutrition Discussion Forum) 389.

Habas, M. Elmukhtar \& Macdonald, I. A. Metabolic and cardiovascular responses to liquid and solid test meals 241 .

Hachey, David L. see Dawson, Janet M. 275.

Hanigan, M. D., France, J., Wray-Cahen, D., Beever, D. E., Lobley, G. E., Reutzel, L. \& Smith, N. E. Alternative models for analyses of liver and mammary transorgan metabolite extraction data 63.

Harding, M. see Amarri, S. 541.

Harris, H. E., Ellison, G. T. H., Richter, L. M., De Wet, T. \& Levin, J. Are overweight women at increased risk of obesity following pregnancy? 489.

Hase, T. see Mazur, W. M. 37.
Haywood, Susan, Dincer, Zuhal, Holding, J. \& Parry, Nicola M. Metal (molybdenum, copper) accumulation and retention in brain, pituitary and other organs of ammonium tetrathiomolybdate-treated sheep (Short communication) 329

Heasman, Lindsay see Clarke, Lynne 359.

Hegarty, R. S., McPhee, M. J., Oddy, V. H., Thomas, B. J. \& Ward, L. C. Prediction of the chemical composition of lamb carcasses from multi-frequency impedance data 169.

Henry, C. J. K., Ghusain-Choueiri, A. \& Payne, P. R. Energy partitioning between body storage of protein and fat during starvation and refeeding: sources of intra-individual variation of P-ratios (reply) (Nutrition Discussion Forum) 109.

Higashi, Yusuke, Takenaka, Asako, Takahashi, Shin-Ichiro \& Noguchi, Tadashi. Effect of protein restriction on messenger RNA of insulin-like growth factor-I and insulinlike growth factor-binding proteins in liver of ovariectomized rats 447 .

Holding, J. see Haywood, Susan 329.

House, William see Benito, Paloma 533.

Huddle, Janet-Marie, Gibson, Rosalind S. \& Cullinan, Timothy R. Is zinc a limiting nutrient in the diets of rural pregnant Malawian women? 257.

Huhtanen, Pekka, Vanhatalo, Aila \& Varvikko, Tuomo. Enzyme activities of rumen particles and feed samples incubated in situ with differing types of cloth 161 .

Hurrell, Richard F., Davidsson, Lena, Reddy, Manju, Kastenmayer, Peter \& Cook, James D. A comparison of iron absorption in adults and infants consuming identical infant formulas 31 .

Idoate, Isabel see Urdaneta, Elena 439.

Ilic, Vera see Summers, Lucinda K. M. 141.

Ishikawa, F. see Kikuchi-Hayakawa, H. 97.

Jackson, Kim G. see Roche, Helen M. 419.

James, L. A., Lunn, P. G. \& Elia, M. Glutamine metabolism in the gastrointestinal tract of the rat assessed by the relative activities of glutaminase (EC 3.5.1.2) and glutamine synthetase (EC 6.3.1.2) 365 .

Jerling, Johann C. see Loktionov, Alexandre 133.

Juniper, Darren T. see Clarke, Lynne 359.

Kastenmayer, Peter see Hurrell, Richard F. 31.

Keller, W. L. see Kim, S. H. 177.

Kikuchi-Hayakawa, H., Onodera, N., Matsubara, S., Yasuda, E., Shimakawa, Y. \& Ishikawa, F. Effects of soya milk and Bifidobacterium-fermented soya milk on plasma and liver lipids, and faecal steroids in hamsters fed on a cholesterol-free or cholesterol-enriched diet 97.

Kim, S. H., Moon, Y. S., Keller, W. L. \& Park, C. S. Compensatory nutrition-directed mammary cell proliferation and lactation in rats 177.

Kirschner, P. A. see Westerterp-Plantenga, M. S. 479.

Koussouri, Mary see Petridou, Eleni 407.

Kunath-Rau, Angelika see Trautwein, Elke A. 463.

Kuusela, Pertti J. see Evans, Kevin 425.

Kyriazakis, I., Anderson, D. H. \& Duncan, A. J. Conditioned flavour aversions in sheep: the relationship between the dose rate of a secondary plant compound and the acquisition and persistence of aversions 55.

Lambert, Marc S., Avella, Michael A., Botham, Kathleen M. \& Mayes, Peter A. Comparison of short- and long-term effects of different dietary fats on the hepatic uptake and metabolism of chylomicron remnants in rats 203.

Larralde, Jesús see Urdaneta, Elena 439.

Laugharne, Jonathan D. see Wells, Anita S. 23.

Lawson, Nigel see Salter, Andrew M. 195. 
Lecozler, Y. see van Milgen, J. 509.

Le Huërou-Luron, Isabelle see Zabielski, Romuald 287.

Levin, J. see Harris, H. E. 489.

Liggins, J. see Bingham, S. A. 393.

Liu, S. M., Mata, G., O'Donoghue, H. \& Masters, D. G. The influence of live weight, live-weight change and diet on protein synthesis in the skin and skeletal muscle in young Merino sheep 267.

Lobley, G. E. see Hanigan, M. D. 63.

Lobley, G. E. see Sarraseca, A. 79.

Loktionov, Alexandre, Bingham, Sheila A., Vorster, Hester, Jerling, Johann C., Runswick, Shirley A. \& Cummings, John H. Apolipoprotein $E$ genotype modulates the effect of black tea drinking on blood lipids and blood coagulation factors: a pilot study 133.

Lopez, S. see France, J. 314.

López-Sobaler, Ana M. see Ortega, Rosa M. 431.

López-Sobaler, Ana M. see Ortega, Rosa M. 501.

Lunn, P. G. see James, L. A. 365.

Lunn, Peter G. see Sawaya, Ana Lydia 455.

Macdonald, I. A. see Habas, M. Elmukhtar 241.

McMurtry, J. P. see Rosebrough, R. W. 89.

McPhee, M. J. see Hegarty, R. S. 169.

Mangiapane, E. Heather see Salter, Andrew M. 195.

Marenah, Christine B. see Salter, Andrew M. 195.

Margetts, Barrie, Buttriss, Judy \& Frayn, Keith Public health nutrition comes of age (Guest editorial) 225.

Martín-Orúe, S. M. see Pérez, J. F. 237.

Martín-Orúe, S. M. see Balcells, J. 373.

Martínez, Rosa M. see Ortega, Rosa M. 431.

Martínez, Rosa M., see Ortega, Rosa M. 501.

Masters, D. G. see Liu, S. M. 267.

Mata, G. see Liu, S. M. 267.

Mathers, J. C., Smith, Helen \& Carter, Sophie Dose-response effects of raw potato starch on small-intestinal escape, largebowel fermentation and gut transit time in the rat (Corrigendum) 223.

Matsubara, S. see Kikuchi-Hayakawa, H. 79.

Matthews, Dwight E. see Bäurle, Wolfgang 381.

Mayes, Peter A. see Lambert, Marc S. 203.

Mazur, W. M., Wähälä, K., Rasku, S., Salakka, A., Hase, T. \& Adlercreutz, H. Lignan and isoflavonoid concentrations in tea and coffee 37.

Meallet, Chrystel see Palmer, Robert M. 351.

Metcalf, M. J. see Sarraseca, A. 79.

Miller, Dennis see Benito, Paloma 533.

Millward, D. Joe \& Wijesinghe, D. G. N. G. Energy partitioning and the regulation of body weight (reply) (Nutrition Discussion Forum) 111.

Milne, E. see Sarraseca, A. 79.

Moon, Y. S. see Kim, S. H. 177.

Muskiet, Frits A. J. see Brouwer, D. A. Janneke 527.

Noblet, J. see van Milgen, J. 509.

Noguchi, Tadashi see Higashi, Yusuke 447.

Oddy, V. H. see Hegarty, R. S. 169.

O'Dea, Kerin see Soares, Mario J. 333.

O'Donoghue, H. see Liu, S. M. 267.

Olsen, Jorn see Petridou, Eleni 407.

O'Neill, M. E. \& Thurnham, D. I. Intestinal absorption of $\beta$ carotene, lycopene and lutein in men and women following a standard meal: response curves in the triacylglycerol-rich lipoprotein fraction 149.

Onodera, N. see Kikuchi-Hayakawa, H. 97.

Oostdam, Arno J. see Groot, Jeroen C. J. 519.

Ortega, Rosa M., Quintas, M. Elena, Andrés, Pedro, Martínez, Rosa M. \& López-Sobaler, Ana M. Ascorbic acid levels in maternal milk: differences with respect to ascorbic acid status during the third trimester of pregnancy 431.

Ortega, Rosa M., Martínez, Rosa M., Quintas, M. Elena, LópezSobaler, Ana M. \& Andrés, Pedro. Calcium levels in maternal milk: relationships with calcium intake during the third trimester of pregnancy 501.

Owen, R. W. see Reddy, Sheela 495.

Palmer, Robert M., Thompson, Michael G., Meallet, Chrystel, Thom, Amanda, Aitken, Raymond P. \& Wallace, Jacqueline M. Growth and metabolism of fetal and maternal muscles of adolescent sheep on adequate or high feed intakes: possible role of protein kinase $C-\alpha$ in fetal muscle growth 351.

Pantelakis, Stephanos see Petridou, Eleni 407.

Papavassiliou, Antigoni see Petridou, Eleni 407.

Park, C. S. see Kim, S. H. 177.

Parker, Stuart G. see Gariballa, Salah E. 481.

Parry, Nicola M. see Haywood, Susan 329.

Patureau Mirand, Philippe see Savary, Isabelle 297.

Payne, P. R. see Henry, C. J. K. 109.

Pell, Jennifer M. see Dawson, Janet M. 275.

Pencharz, P. B. see Sarwar, G. 129.

Pennington, C. R. Malnutrition in hospital: the case of the stroke patient (Invited commentary) 477.

Pérez, J. F., Balcells, J., Cebrián, J. A. \& Martín-Orúe, S. M. Excretion of endogenous and exogenous purine derivatives in sheep: effect of increased concentrate intake (Short communication) 237.

Pérez, J. F. see Balcells, J. 373.

Petridou, Eleni, Koussouri, Mary, Toupadaki, Nektaria, Youroukos, Sotiris, Papavassiliou, Antigoni, Pantelakis, Stephanos, Olsen, Jorn \& Trichopoulois, Dimitrios. Diet during pregnancy and the risk of cerebral palsy 407.

Piers, Leonard S. see Soares, Mario J. 333.

Pogan, Karin see Bäurle, Wolfgang 381.

Poppi, Dennis P. see Dynes, Robyn A. 47.

Prugnaud, Jacques see Savary, Isabelle 297.

Pusztai, A., Grant, G., Buchan, W. C., Bardocz, S., de Carvalho, A. F. F. U. \& Ewen, S. W. B. Lipid accumulation in obese Zucker rats is reduced by inclusion of raw kidney bean (Phaseolus vulgaris) in the diet 213.

Quinlan, Paul T. see Summers, Lucinda K. M. 141.

Quintas, M. Elena see Ortega, Rosa M. 431.

Quintas, M. Elena see Ortega, Rosa M. 501.

Rasku, S. see Mazur, W. M. 37.

Read, Nicholas W. see Wells, Anita S. 23.

Reddy, Manju see Hurrell, Richard F. 31.

Reddy, Sheela, Sanders, T. A. B., Owen, R. W. \& Thompson M. H. Faecal pH, bile acid and sterol concentrations in premenopausal Indian and white vegetarians compared with white omnivores 495.

Reeds, Peter J. see Dawson, Janet M. 275.

Reutzel, L. see Hanigan, M. D. 63.

Richter, L. M. see Harris, H. E. 489.

Robinson, Siân, Godfrey, Keith, Denne, Jonathan \& Cox, Vanessa. The determinants of iron status in early pregnancy 249.

Roche, Helen M., Zampelas, Antonis, Jackson, Kim G., Williams, Christine M. \& Gibney, Michael J. The effect of test meal monounsaturated fatty acid: saturated fatty acid ratio on postprandial lipid metabolism 419.

Rosebrough, R. W., McMurtry, J. P. \& Vasilatos-Younken, R. Further studies on carry-over effects of dietary crude protein and triiodothyronine $\left(T_{3}\right)$ in broiler chickens 89.

Runswick, Shirley A. see Loktionov, Alexandre 133.

Salakka, A. see Mazur, W. M. 37. 
Salter, Andrew M., Mangiapane, E. Heather, Bennett, Andrew J., Bruce, Jennifer S., Billett, Michael A., Anderton, Kay L., Marenah, Christine B., Lawson, Nigel \& White, David A. The effect of different dietary fatty acids on lipoprotein metabolism: concentration-dependent effects of diets enriched in oleic, myristic, palmitic and stearic acids 195.

Sánchez-Pozo, Antonio. The role of dietary nucleotides in nutrition (reply) (Nutrition Discussion Forum) 107.

Sanders, T. A. B. see Reddy, Sheela 495.

Sarraseca, A., Milne, E., Metcalf, M. J. \& Lobley, G. E. Urea recycling in sheep: effects of intake 79.

Sarwar, G., Botting, H. G., Davis, T. A., Darling, P. \& Pencharz, P. B. Free amino acids in milks of human subjects, other primates and non-primates (Short communication) 129.

Savary, Isabelle, Debras, Elisabeth, Dardevet, Dominique, Sornet, Claire, Capitan, Pierre, Prugnaud, Jacques, Patureau Mirand, Philippe \& Grizard, Jean. Effect of glucocorticoid excess on skeletal muscle and heart protein synthesis in adult and old rats 297.

Sawaya, Ana Lydia \& Lunn, Peter G. Lowering of plasma triiodothyronine level and sympathetic activity does not alter hypoalbuminaemia in rats fed on a diet of low protein concentration 455.

Shetty, Prakash S. see Soares, Mario J. 333.

Shimakawa, Y. see Kikuchi-Hayakawa, H. 97.

Smith, Helen see Mathers, J. C. 223.

Smith, N. E. see Hanigan, M. D. 63.

Soares, Mario J., Piers, Leonard S., O’Dea, Kerin \& Shetty, Prakash S. No evidence for an ethnic influence on basal metabolism: an examination of data from India and Australia 333.

Sornet, Claire see Savary, Isabelle 297.

Summers, Lucinda K. M., Fielding, Barbara A., Ilic, Vera, Quinlan, Paul T. \& Frayn, Keith N. The effect of triacylglycerol-fatty acid positional distribution on postprandial metabolism in subcutaneous adipose tissue 141.

Sykes, Andrew R. see Dynes, Robyn A. 47.

Symonds, Michael E. see Clarke, Lynne 359.

Takahashi, Shin-Ichiro see Higashi, Yusuke 447.

Takenaka, Asako see Higashi, Yusuke 447.

Tamminga, Seerp see Groot, Jeroen C. J. 519.

Taub, Nick see Gariballa, Salah E. 481.

Thom, Amanda see Palmer, Robert M. 351.

Thomas, B. J. see Hegarty, R. S. 169.

Thompson, M. H. see Reddy, Sheela 495.

Thompson, Michael G. see Palmer, Robert M. 351.

Thurnham, D. I. see O'Neill, M. E. 149.

Thurnham, D. I. see Adelekan, D. A. 305.

Toupadaki, Nektaria see Petridou, Eleni 407.

Trautwein, Elke A., Kunath-Rau, Angelika \& Erbersdobler, Helmut F. Effect of different varieties of pectin and guar gum on plasma, hepatic and biliary lipids and cholesterol gallstone formation in hamsters fed on high-cholesterol diets 463.

Tremblay, Angelo, Drapeau, Vicky, Doucet, Eric, Alméras, Natalie, Després, Jean-Pierre \& Bouchard, Claude. Fat balance and ageing: results from the Québec Family Study 413.
Trichopoulos, Dimitrios see Petridou, Eleni 407

Tsuchiya, H, \& Bates, C. J. Vitamin C and copper interactions in guinea-pigs and a study of collagen cross-links (Corrigendum) 313.

Urdaneta, Elena, Idoate, Isabel \& Larralde, Jesús Drug-nutrient interactions: inhibition of amino acid intestinal absorption by fluoxetine 439.

van Beek, Jackelien see Brouwer, D. A. Janneke 527. van der Heiden, H. Jacoline see Brouwer, D. A. Janneke 527. van der Klis, Fiona R. M. see Brouwer, D. A. Janneke 527. van der Vusse, Ger J. see Brouns, Fred. 117.

Vanhatalo, Aila see Huhtanen, Pekka 161.

van Milgen, J., Bernier, J. F., Lecozler, Y., Dubois, S. \& Noblet, J. Major determinants of fasting heat production and energetic cost of activity in growing pigs of different body weight and breed/castration combination 509.

Varvikko, Tuomo see Huhtanen, Pekka 161.

Vasilatos-Younken, R. see Rosebrough, R. W. 89.

Verstraete, W. see de Smet, I. 185.

Vorster, Hester see Loktionov, Alexandre 133.

Wähälä, K. see Mazur, W. M. 37.

Walker, Alexander R. P. The remedying of iron deficiency: what priority should it have? (Review article) 227.

Wallace, Jacqueline M. see Palmer, Robert M. 351.

Ward, L. C. see Hegarty, R. S. 169.

Weaver, L. T. see Amarri, S. 541.

Wells, Anita S., Read, Nicholas W., Laugharne, Jonathan D. E. \& Ahluwalia, N. S. Alterations in mood after changing to a lowfat diet 23.

Westerterp-Plantenga, M. S. \& Kirschner, P. A. Information and communication technology in nutrition and dietetic education (Invited commentary) 479.

White, David A. see Salter, Andrew M. 195.

Wijesinghe, D. G. N. G. see Millward, D. Joe 111.

Wilhelmova, Ingrid see Evans, Kevin 425.

Williams, Barbara A. see Groot, Jeroen C. J. 519.

Williams, Christine M. Gene-nutrient interactions: an important area for consideration (Invited commentary) 115.

Williams, Christine M. see Roche, Helen M. 419.

Wise, A. Information technology in nutrition and dietetic education (Letter to the Editors) 547.

Wray-Cahen, D. see Hanigan, M. D. 63.

Yasuda, E. see Kikuchi-Hayakawa, H. 97.

Youroukos, Sotiris see Petridou, Eleni 407

Zabielski, Romuald, Dardillat, Claude, Le Huërou-Luron, Isabelle, Bernard, Christine, Chayvialle, Jean Alain \& Guilloteau, Paul. Periodic fuctuations of gut regulatory peptides in phase with the duodenal migrating myoelectric complex in preruminant calves: effect of different sources of dietary protein 287.

Zampelas, Antonis see Roche, Helen M. 419. 